\title{
STRATEGI PENGEMBANGAN INDUSTRI KREATIF SEKTOR KERAJINAN PERHIASAN MUTIARA DI KOTA MATARAM
}

\author{
H. M. Ilhamuddin ${ }^{1}$, Rusminah ${ }^{2}$, Hj. Hilmiati ${ }^{3}$ dan M. Ahyar ${ }^{4}$
}

\author{
Fakultas Ekonomi dan Bisnis Universitas Mataram
}

\begin{abstract}
ABSTRAK
This study is aimed to find out an alternative strategies of creative industry development of pearl jewelry craft sector in Mataram city. The research uses descriptive research design. The data collected by interview and observation methods which is analyzed by using Internal Factor Analysis (IFE), External Factor Analysis (EFE), and SWOT analysis. The results shows that the internal environment of the industry has a strong position where the strength has a total value of 2.46 compared to the weakness of 0.64 . The industry's position of the outside environment also has strong position where the industry 's opportunity has a total value of 1.80 versus threat 1.04 . Based on the value of IFE and EFE can be obtained coordinate point in the axis system is $0.91,0.38$. The strategy choice is a growth strategy.
\end{abstract}

Keyword: development Strategy, SWOT, creative industry of pearl jewelry

\section{PENDAHULUAN}

Persaingan global, menuntut daerah untuk mampu menghasilkan output secara efisien, agar tetap dapat bertahan. Efisiensi memicu timbulnya pemikiran kreatif, yang pada akhirnya dapat memunculkan ide kreatif. Ekonomik reatif yang identik dengan industri kreatif, pada saat ini dianggap dapat memberikan kontribusi yang sangat signifikan, bagi perekonomian daerah. Dan keberadaannya merupakan bagian yang tidak dapat dipisahkan. Menurut UNCTAD (2008), industri kreatif banyak memberikan kontribusi secara nyata pada perekonomian Negara, yaitu peningkatan nilai eksport, penyerapan tenaga kerja dalam jumlah besar, serta satu penyumbang produk domestik bruto (PDRB).

Pendapat tersebut didukung dengan pendapat Depertemen Perdagangan (2008), mencatat bahwa kontribusi industri kreatif terhadap PDB ditahun 2002 hingga 2006 rata rata mencapai $6,3 \%$ atau setara dengan 152,5 trilyun jika dirupiahkan. Industri kreatif sanggup menyerap tenaga kerja hingga 5,4juta dengan tingkat partisipasi 5,8\%. Sedangkan dari segi ekspor, industri kreatif membukukan total ekspor 10,6\% antara tahun 2002 hingga 2006.

Salah satu alasan dari pengembangan potensi industri kreatif adalah adanya dampak positif yang akan berpengaruh pada kehidupan sosial, iklim bisnis, peningkatan ekonomi, dan juga berdampak pada citra suatu kawasan tersebut. Hal pendorong tersebut disebabkan karena sesuatu yang baru, baik menyangkut produk barang ataupun jasa, selalu mendorong orang untuk mendatangi, melihat, mengetahui, merasakan, atau bahkan ingin memilik bila sesuatu itu bisa diperdagangkan. Demikian juga dengan industri kreatif, baik sesuatu yang baru sama sekali, inovasi terhadap sesuatu yang sudah ada ataupun mencontoh di tempat lain, akan mendorong orang untuk mengetahui keberadaan sesuatu yang baru tersebut. Dengan demikian, keberadaan industri kreatif secara langsung 
ataupun tidak langsung merupakan obyek dan daya tarik wisata yang dapat mendorong orang untuk datang atau mengunjungi keberadaan industri kreatif tersebut.

Kota Mataram NTB sebagai salah satu kota di Indonesia mempunyai potensi industri kreatif yang apabila dikelola dengan baik akan menjadi salah satu penggerak destinasi parisiwata di tempat tersebut. Salah satu industri kreatif yang mempunyai prospek bagus yaitu kerajinan perhiasan mutiara yang tersebar di sentra kerajinan Sekarbela kota Mataram. Jenis kerajinan ini mempunyai peran tersendiri karena telah memiliki potensi pasar internasional, serta juga menyertakan kearifan lokal dalam penggunaan faktor produksi.

Dalam industri kreatif kerajinan perhiasan mutiara, terdapat permasalahan dari lingkungan internal maupun eksternal industri. Lingkungan bisnis menuntut setiap industri dan perusahaan mampu beradaptasi dengan perubahan yang terjadi. Industri perhiasan mutiara melekat muatan fashion didalamnya, gerakan perubahan selera pasar lebih pesat pada jenis industri ini. Selain itu penggunaan tehnologi akan menjadi utama manakala beberapa bagian dari proses produksi akan lebih efektif dan efisien bila menggunakan tehnologi.

Persaingan yang semakin ketat pada produk perhiasan mutiara, baik pesaing domestik maupun asing, belum direnspon dengan mengimplementasikan konsep bisnis yang relevan. Banyak hal-hal kecil dalam industri ini namun mempunyai dampak yang besar ketika suatu perusahaan dalam industri memperluas wilayah pemasarannya. Konsep bauran produk misalnya yang berhubungan dengan kemasan dan branding. Meskipun kualitas produk tinggi namun tidak dipersepsi "lebih baik" oleh pasar maka pasti akan mengalami kesulitan dalam pemasaran.

Melihat permasalahan yang ada pada industri kerajinan perhiasan mutiara diatas, maka diperlukan strategi-strategi untuk mengembangkan industri kerajinan tersebut. Selama ini telah banyak upaya pembinaan dan pemberdayaan yang dilakukan oleh pihakpihak terkait, baik institusi pemerintah maupun swasta. Upaya-upaya yang dilakukan tersebut belum dapat berfungsi secara maksimal terhadap perkembangan industri. Hal ini dikarenakan pembinaan yang dilakukan selama ini sering tumpang tindih dan dilakukan sendiri-sendiri oleh masing-masing institusi tanpa adanya saling koordinasi yang baik sehingga pembinaan dan pemberdayaan kurang efektif dan efisien.

Berdasarkan uraian tersebut, maka penulis tertarik untuk meneliti "Strategi Pengembangan Industri Kreatif Sektor Kerajinan Perhiasan Mutiara di Kota Mataram"

\section{KAJIAN TEORITIS}

\subsection{Industri Kreatif}

Menurut DCMS (Creative Digital Industries National Mapping Project ARC Centre of Excellent for Creative Industries and Innovation, 2007) industri kreatif adalah industri yang berasal dari pemanfaatan kreatifitas, keterampilan serta bakat individu untuk menciptakan kesejahteraan serta lapangan pekerjaan melalui penciptaan dan pemanfaatan daya kreasi dan daya cipta individu tersebut (BPEN/WRT/0011112009 edisi Januari). Sedangkan Mohammad Adam Jerusalem (2009), bahwa industri kreatif adalah industri yang mempunyai keaslian dalam kreatifitas individual, ketrampilan dan bakat yang mempunyai potensi untuk mendatangkan pendapatan dan penciptaan lapangan kerja melalui eksploitasi kekayaan intelektual.

Sedangkan United Nations Conference on Trade and Development UNCTAD (2008) dalam Mohammad Adam Jerusalem (2009), industri kreatif adalah: 


\section{$J M M$ UNRAM \\ JURNAL MAGISTER MANAJEMEN \\ UNIVERSITAS MATARAM \\ Maret 2018 \\ e- issn : 2548-3919}

1. Siklus kreasi, produksi, dan distribusi dari barang dan jasa yang menggunakan modal kreatifitas dan intelektual sebagai input utamanya;

2. Bagian dari serangkaian aktivitas berbasis pengetahuan, berfokus pada seni, yang berpotensi mendatangkan pendapatan dari perdagangan dan hak atas kekayaan intelektual;

3. Terdiri dari produk-produk yang dapat disentuh dan intelektual yang tidak dapat disentuh atau jasa-jasa artistik dengan muatan kreatif, nilai ekonomis, dan tujuan pasar;

4. Bersifat lintas sektor antara seni, jasa, dan industri; dan

5. Bagian dari suatu sektor dinamis bam dalam dunia perdagangan.

Berdasarkan berbagai pendapat di atas, industri kreatif merupakan industri yang mendasarkan pada inovasi, ide-ide baru dari sumber daya manusia yang kreatif.

Menurut Departemen Perdagangan Republik Industri dalam buku Pengembangan Industri Kreatif Menuju Visi Ekonomi Kreatif 2025, industri kreatif dapat dikelompokkan menjadi 14 sub sektor, dan dalam perkembangannya ditambah satu sub sektor yaitu:

1. Periklanan (advertising)

2. Arsitektur

3. Pasar Barang Seni

4. Kerajinan (craft)

5. Desain

6. Fesyen (fashion)

7. Video, Film dan Fotografi

8. Permainan Interaktif (Interactive Games)

9. Musik

10.Seni Pertunjukan (showbiz)

11.Penerbitan dan Percetakan

12.Layanan Komputer dan Piranti Lunak (software)

13.Televisi \& Radio (broadcasting)

14. Riset dan Pengembangan (R\&D)

15. Kuliner

Ekonomi kreatif akan menjadi potensial apabila didukung tiga hal, yaitu Knowledge Creative (Pengetahuan yang kreatif), Skilled Worker (pekerja yang berkemampuan), Labor Intensive (kekuatan tenaga kerja) untuk dapat dipergunakan kepada begitu banyak ruang dalam industri produk kreatif yang terns berkembang di Indonesia, seperti crafts, advertising, publishing and printing, television and radio, architecture, music, design, dan fashion (Betti Alisjahbana (2009).

\subsection{Industri Kerajinan}

Berdasarkan hasil Simposium Internasional UNESCO/ITC di Manila tahun 1997, kerajinan adalah industri yang menghasilkan produk-produk, baik secara keseluruhan menggunakan tangan atau menggunakan peralatan biasa, peralatan mekanis mungkin juga digunakan sepanjang kontribusi para pengrajin tetap lebih substansial pada komponen produk akhir. Kegiatan kerajinan merupakan kegiatan kreatif yang berkaitan dengan kreasi, produksi dan distribusi produk yang dibuat dan dihasilkan oleh tenaga pengrajin yang berawal dari desain awal sampai dengan proses penyelesaian produknya antara lain meliputi barang kerajinan yang terbuat dari batu berharga, serat alam maupun buatan, kulit, rotan, bambu, kayu, logam (emas, perak, tembaga, perunggu, besi), kaca, porselin, marmer, tanah liat dan kapur. 
Produk kerajinan pada umumnya hanya diproduksi dalam jumlah yang relatif kecil (bukan produksi massal). Volume produksi yang dihasilkan oleh kelompok industri kerajinan ini sangat bergantung pada jumlah dan keahlian tenaga pengrajin yang tersedia sehingga kelompok industri ini dapat dikategorikan sebagai industri padat karya.

Berdasarkan bahan baku yang digunakan produk kerajinan dapat dikategorikan sebagai berikut:

1. Keramik, seperti tanah liat, earthenware, pottery, stoneware, porcelain.

2. Logam, seperti emas, perak, tembaga, perunggu, besi.

3. Natural fiber, seperti serat alam (bambu, akar-akaran, rotan)

4. Batu-batuan, seperti batu mulia, semi precious stone, jade

5. Tekstil, seperti katun, sutra dan linen

6. Kayu, seperti kertas dan lacquer ware

\subsection{Strategi Pengembangan}

Strategi itu sendiri memiliki arti bahwa semua kegiatan yang ada dalam lingkup perusahaan,termasuk di dalamnya pengalokasian sumber daya yang dimiliki perusahaan.Sedangkan menurut (Hill,1989), strategi merupakan suatu cara yang berkaitan dengan kegiatan manufaktur dan pemasaran, semuanya bertujuan untuk mengembangkan perspektif corporat melalui agragesi.

Menurut (Rangkuti,2009:4) konsep-konsep strategi ada dua yaitu:

1. Distinctive Competence merupakan tindakan yang dilakukan oleh perusahaan agar dapat melakukan kegiatan lebih baik dibandingkan dengan pesaingnya. Suatu perusahaan yang memiliki kekuatan yang tidak mudah ditiru oleh perusahaan pesaing dipandang sebagai perusahaan yang memiliki "Distinctive Competence". Distinctive Competence menjelaskan kemampuan spesifik suatu organisasi. Identifikasi Distinctive Competence dalam suatu organisasi meliputi:

a. Keahlian tenaga kerja

b. Kemampuan sumber daya

Dua faktor tersebut menyababkan perusahaan dapat lebih unggul dibandingkan dengan pesaingnya . keahlian sumber daya manusia yang tinggi muncul dari kemampuan membentuk fungsi khusus yang lebih efektif dibandingkan dengan pesaing. Dengan memiliki kemampuan melakukan riset pemasaran yang lebih baik, perusahaan dapat mengetahui secara tepat semua keinginan konsumen sehingga dapat menyusun strategistrategi pemasaran yang lebih baik dibandingkan dengan pesaingnya. Semua kekuatan tersebut dapat diciptakan melalui penggunaan seluruh potensi sumber daya yang dimiliki perusahaan, seperti peralatan dan proses produksi yang canggih, penggunaan jaringan saluran distribusi cukup luas, penggunaan sumber bahan baku yang tinggi kualitasnya dan brand image yang positif serta sistem reservasi yang terkomputerisasi.

2. Competetive Advantage merupakan pilihan strategi yang dilakukan perusahaan untuk merebut peluang pasar. Menurut Porter (dalam skripsi Hidayat,2009:25)
a. Cost leadership
b. Diferensiasi
c. Fokus

Perusahaan dapat memperoleh keunggulan bersaing yang lebih tinggi dibandingkan dengan pesaingnya jika dia dapat memberikan harga jual yang lebih murah dari harga yang diberikan oleh pesaingnya dengan nilai atau kualitas produk yang sama. Harga jual yang lebih rendah dapat dicapai oleh perusahaan tersebut karena dia dapat memanfaatkan 


\section{$J M M$ UNRAM

skala ekonomis, efisiensi produksi, penggunaan teknologi, kemudahan akses dengan bahan baku, dan sebagainya

Perusahaan juga dapat melakukan strategi diferensiasi dengan menciptakan persepsi terhadap nilai tertentu pada konsumennya. Selain itu, strategi fokus juga dapat diterapkan untuk memperoleh keunggulan bersaing sesuai dengan segmentasi dan pasar sasaran yang diharapkan.

\section{METODE PENELITIAN}

\subsection{Jenis Penelitian}

Metode penelitian yang akan digunakan dalam penulisan skripsi ini adalah metode penelitian deskriptif kuantitatif, yaitu apabila datanya telah terkumpul, lalu diklasifikasikan menjadi dua kelompok data, yaitu data kuantitatif yang berbentuk angka dan data kualitatif yang dinyatakan dalam kata- kata atau simbol. Data kualitatif yang berbentuk kata-kata tersebut disisihkan untuk sementara, karena akan sangat berguna untuk menyertai dan melengkapi gambaran yang diperoleh dari analisis data kuantitatif. Data yang diperoleh dari angka, dijumlahkan atau dikelompokkan sesuai dengan bentuk instrumen yang digunakan (Arikunto, 2002: 213).

\subsection{Lokasi Penelitian}

Penelitian dilakukan di kelurahan Kota Mataram karena di tempat tersebut merupakan sentra industri kreatif kerajinan perhiasan mutiara.

\subsection{Metode Pengumpulan Data}

\subsubsection{Wawancara}

Wawancara merupakan bagian dari tehnik komunikasi dimana pencari data mengadakan tanya jawab dengan nara sumber untuk menggali data yang diperlukan. Dengan wawancara ini keterangan dan informasi tentang data-data yang berhubungan dengan penelitian dapat diperoleh melalui wawancara dengan pengusaha, pegawai pemerintah terkait dan lain-lain. Wawancara dilakukan untuk memperoleh data dari pengusaha pada industri kerajinan perhiasan mutiara di kota Mataram maupun dari instansi- instansi terkait. Wawancara dilakukan untuk mengumpulkan data tentang kekuatan, kelemahan, peluang dan ancaman dari industri kreatif tersebut.

\subsubsection{Dokumentasi}

Metode ini digunakan untuk mengumpulkan data fisik dan kondisi usaha industri kerajinan perhiasan mutiara di kota Mataram.

\subsection{Responden Penelitian}

Populasi dalam penelitian ini adalah pengusaha kerajinan perhiasan mutiara yang tersebar di Sekarbela Kota Mataram. Oleh karena populasi tidak diketahui secara pasti maka penentuan sampelnya ditentukan secara non-probability sampling dengan tehnik pengambilan sampelnynya adalah purposive sampling. Purposive sampling adalah tehnik pengambilan sampel yang dilakukan atas dasar kriteria tertentu. Dalam penelitian ini kriteria sampelnya adalah para pengusaha yang sudah menekumi usahanya lebih dari 3 tahun. Untuk jumlah sampel dalam penelitian ini adalah 36 pengusaha. Jumlah ini merujuk 
pada pendapat Roscoe (1975, dalam Sekaran 2006) yang mengatakan bahwa ukuran sampel lebih dari 30 dan kurang dari 500 adalah tepat untuk kebanyakan penelitian.

\subsection{Variabel Penelitian}

Variabel yang digunakan dalam penelitian ini adalah sebagai berikut:

1. Lingkungan internal yaitu lingkungan yang berhubungan dengan kegiatan internal industri kreatif kerajinan perhiasan mutiara kota Mataram yang meliputi kekuatan dan kelemahan industri. Indikator dari variabel kekuatan dan kelemahan digali dari manajemen SDM, produksi, pemasaran dan organisasi.

2. Lingkungan eksternal lingkungan yang berhubungan dengan lingkungan makro dan meso dari bisnis kerajinan perhiasan mutiara tersebut meliputi variabel peluang dan ancaman yang dihadapi perusahaan perusahaan dalam industri. Indikator dari variabel peluang dan ancaman berasal dari faktor ekonomi, sosial, budaya, tehnologi, dan persaingan.

\subsection{Tehnik Analisa}

Data hasil penelitian dikumpulkan ditabulasi dan dianalisis. Analisis data dalam penelitian ini menggunakan beberapa pendekatan sebagai berikut:

\subsubsection{Analisis Deskriptif}

Analisis deskriptif merupakan analisis yang berguna untuk menggambarkan variabel yang diteliti ( Arikunto, 2000: 213). Yaitu hasil penelitian ini hanya untuk menggambarkan atau melukiskan keadaan suatu obyek penelitian pada saat sekarang berdasarkan faktafakta yang tampak atau sebagaimana adanya. Analisis ini untuk mengetahui tentang profil industri kreatif kerajinan perhiasan mutiara di kota Mataram.

\subsubsection{Analisis SWOT}

Analisis SWOT adalah identifikasi berbagai faktor secara sistematis untuk merumuskan faktor-faktor pendorong dan penghambat pertumbuhan dan perkembangan sektor industri kreatif sektor kerajinan perhiasan mutiara. Analisis ini didasarkan pada logika yang dapat memaksimalkan kekuatan (strength) dan peluang (opportunities), namun secara bersamaan dapat meminimalkan kelemahan (weakness) dan ancaman (treats). Hal ini disebut dengan analisis situasi. Model yang paling popular untuk analisis situasi adalah analisis SWOT (Rangkuty, 1998:19).

Analisis SWOT membandingkan faktor eksternal peluang (opportunities) dan ancaman (treats) dengan faktor internal kekuatan (strength) dan kelemahan (weakness), untuk menghasilkan analisis yang tepat.

\section{HASIL DAN PEMBAHASAN}

Analisis data dalam penelitian ini mencakup analisis faktor internal dan analisis faktor eksternal industri kreatif sektor kerajinan perhiasan mutiara di kota Mataram melalui matrik Internal Factor Evaluation (IFE) dan External Factor Evaluation (EFE). Selanjutnya hasil perhitungan IFE dan EFE akan menggambarkan pisisi industri kreatif sektor kerajinan perhiasan mutiara kota Mataram terhadap pesaingnya.

Faktor internal yang berasal dari dalam lingkungan perusahaan seperti kekuatan dan kelemahan antara lain:

1) Kekuatan (strength) terdiri dari: 


\section{JURNAL MAGISTER MANAJEMEN \\ UNIVERSITAS MATARAM \\ Maret 2018 \\ e- issn : 2548-3919}

UNRAM

a. hand made process sesuai selera pasar,

b. jaringan pemasaran keluar daerah sudang terbangun,

c. kondisi keuangan stabil dan meningkat,

d. reputasi yang baik dalam pelayanan baik dalam pemasaran, produksi dan kecepatan dalam pengiriman barang.

2) kelemahan (weakness) adalah:

a. tidak menggunakan mesin untuk pesanan volume besar sehingga proses produksi lambat,

b. tidak mempunyai desain khusus yang bisa dijadikan komoditi utama,

c. perencanaan produksi masih belum maksimal dan masih ditentukan berdasarkan kebutuhan,

d. dan modal usaha yang besar memiliki risiko tinggi.

3) peluang (opportunity) adalah:

a. minat beli pelanggan yang besar untuk keperluan gaya,

b. dukungan pemerintah dalam pengenalan produk melalui pameran,

c. kenaikan permintaan dalam beberapa tahun terakhir,

d. dukungan pariwisata,

e. dan pelestarian/budi adaya mutiara laut terus berkembang.

4) ancaman (threat) adalah:

a. munculnya Jepang dan Hongkong sebagai kompetitor utama,

b. adanya pesaing dari industri pabrikan,

c. meningkatnya harga bahan baku,

d. dan banyak sektor usaha baru yang membuat pengrajin memilih profesi lain.

Tabel 4.10 Internal Factor Evaluation (IFE)

\begin{tabular}{|c|l|c|c|c|}
\hline No & \multicolumn{1}{|c|}{ Kekuatan dan Kelemahan } & Bobot & Rating & Skor \\
\hline Kekuatan & 0,14 & 4 & 0,56 \\
\hline 1. & $\begin{array}{l}\text { Hand made process sesuai selera } \\
\text { pasar }\end{array}$ & 0,13 & 3 & 0,39 \\
\hline 2. & $\begin{array}{l}\text { Jaringan pemasaran ke luar daerah } \\
\text { sudah terbangun }\end{array}$ & 0,14 & 4 & 0,56 \\
\hline 3. & $\begin{array}{l}\text { Kondisi keuangan stabil dan } \\
\text { meningkat }\end{array}$ & 0,13 & 3 & 0,39 \\
\hline 4. & $\begin{array}{l}\text { Reputasi yang baik dalam } \\
\text { pelayanan baik dalam pemasaran, } \\
\text { produksi dan kecepatan dalam } \\
\text { pengiriman }\end{array}$ & 0,14 & 4 & 0,56 \\
\hline 5. & Keterampilan unik dan diwariskan & $\mathbf{0 , 6 8}$ & $\mathbf{1 8}$ & $\mathbf{2 , 4 6}$ \\
\hline \multicolumn{3}{|c|}{ Total Kekuatan } & 2 & 0,16 \\
\hline Kelemahan & $\begin{array}{l}\text { Tidak menggunakan mesin untuk } \\
\text { pesanan volume besar sehingga } \\
\text { proses produksi lambat }\end{array}$ & 0,08 & 2 & 0,16 \\
\hline 2. & $\begin{array}{l}\text { Tidak mempunyai desain khusus } \\
\text { yang bisa dijadikan komoditi utama }\end{array}$ & 0,08 & 0,16 \\
\hline 3. & $\begin{array}{l}\text { Perencanaan sistem produksi belum } \\
\text { maksimal masih ditentukan }\end{array}$ & 0,08 & 2 & \\
\hline
\end{tabular}




\section{$J M M$ UNRAM

\begin{tabular}{|c|c|c|c|c|}
\hline No & Kekuatan dan Kelemahan & Bobot & Rating & Skor \\
\hline & berdasarkan kebutuhan & & & \\
\hline 4. & $\begin{array}{l}\text { Modal usaha yang besar memiliki } \\
\text { risiko tinggi }\end{array}$ & 0,08 & 2 & 0,16 \\
\hline & Total Kelemahan & 0,32 & 8 & 0,64 \\
\hline & Total Nilai IFE & 1 & 10 & 1,82 \\
\hline
\end{tabular}

Dari tabel diatas dapat dilihat faktor kekuatan perusahaan mempunyai total skor 2,46 sedangkan faktor kelemahan dari industri mempunyai total nilai skor sebesar 0,64. Sehingga faktor kekuatan dari industri lebih besar dari kelemahan industri.

Tabel 4.11 External Factor Evaluation (EFE)

\begin{tabular}{|c|c|c|c|c|}
\hline No & Peluang dan Ancaman & Bobot & Rating & Skor \\
\hline \multicolumn{5}{|c|}{ Peluang } \\
\hline 1. & $\begin{array}{l}\text { Minat beli pelanggan yang besar } \\
\text { untuk keperluan penampilan/gaya }\end{array}$ & 0,12 & 3 & 0,36 \\
\hline 2. & $\begin{array}{l}\text { Dukungan pemerintah dalam } \\
\text { pengenalan produk melalui } \\
\text { pameran-pameran }\end{array}$ & 0,12 & 3 & 0,36 \\
\hline 3. & $\begin{array}{l}\text { Kenaikan permintaan dalam } \\
\text { beberapa tahun terakhir }\end{array}$ & 0,12 & 3 & 0,36 \\
\hline 4. & Dukungan pariwisata & 0,12 & 3 & 0,36 \\
\hline 5. & $\begin{array}{l}\text { Pelestarian dan budidaya mutiara } \\
\text { laut terus berkembang }\end{array}$ & 0,12 & 3 & 0,36 \\
\hline \multicolumn{2}{|r|}{ Total Peluang } & 0,60 & 15 & 1,80 \\
\hline \multicolumn{5}{|c|}{ Ancaman } \\
\hline 1. & $\begin{array}{l}\text { Munculnya Jepang dan Hongkong } \\
\text { sebagai kompetitor utama }\end{array}$ & 0,08 & 2 & 0,16 \\
\hline 2. & $\begin{array}{l}\text { Adanya pesaing dari industri } \\
\text { pabrikan }\end{array}$ & 0,12 & 3 & 0,36 \\
\hline 3. & Meningkatnya harga bahan baku & 0,12 & 3 & 0,36 \\
\hline 4. & $\begin{array}{l}\text { Banyak sektor usaha baru yang } \\
\text { membuat karyawan memilih } \\
\text { profesi lain }\end{array}$ & 0,08 & 2 & 0,16 \\
\hline \multicolumn{2}{|r|}{ Total Ancaman } & 0,4 & 10 & 1,04 \\
\hline \multicolumn{2}{|r|}{ Total Nilai EFE } & 1 & 5 & 0,76 \\
\hline
\end{tabular}

Dari tabel 2 diatas dapat dilihat faktor peluang dari industri mempunyai total nilai skor sebesar 1,80 sedangkan faktor ancaman dari industri mempunyai total nilai skor 1,04. Sehingga faktor peluang dari industri lebih besar dari faktor ancaman dari industri.

Berdasarkan hasil-hasil yang didapat dari analisis internal dan eksternal pada tabeltabel diatas, hasilnya dapat dirangkum sebagai berikut:
1. Skor total kekuatan $=2,46$
2. Skor total kelemahan $=0,64$
3. Skor total peluang $=1,80$
4. Skor total ancaman $=1,04$ 
Nilai faktor kekuatan lebih besar dari faktor kelemahan, demikian pula nilai faktor peluang lebih besar dari faktor ancaman. Ini berarti posisi industri kerajinan perhiasan mutiara kota Mataram berada pada posisi pertumbuhan. Kondisi internal industri kreatif ini cukup kuat dengan lingkungan yang sedikit mengancam. Untuk mencari titik koordinat dalam sistem sumbu dapat dicari melalui cara sebagai berikut:

1. Koordinat Analisis Internal

(Skor Total Kekuatan - Skor Total Kelemahan) / 2

$=2,46-0,64 / 2=0,91$

2. Koordinat Analisis Eksternal

(Skor Total Peluang - Skor Total Ancaman) / 2

$=1,80-1,04 / 2=0,38$

Jadi titik koordinatnya terletak pada 0,$91 ; 0,38$

Berikutnya, hasil koordinat tersebut disajikan dalam diagram matrik SWOT untuk mengetahui posisi riil industri.

Gambar 4. Diagram Matrik SWOT

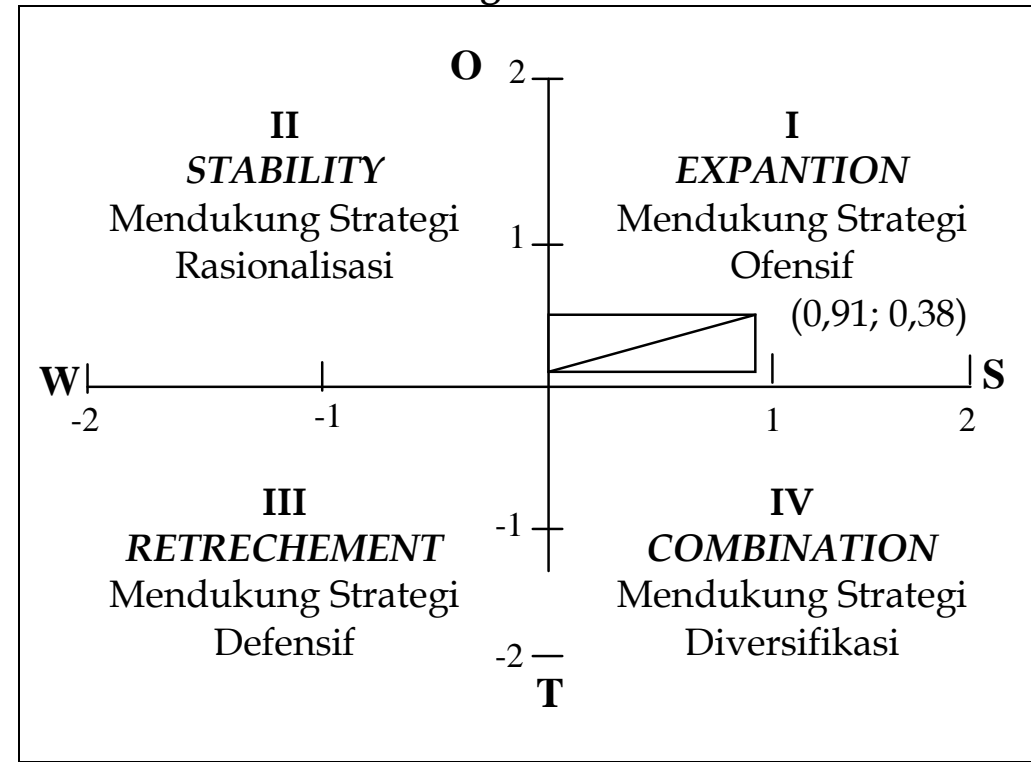

Dari pertemuan titik diagonal tersebut maka diketahui posisi industri kreatif tersebut pada kuadran I. Hasil perhitungan dari masing-masing kuadran dapat digambarkan pada tabel berikut.

Tabel 4.12 Hasil Perhitungan Kuadran

\begin{tabular}{|l|c|c|c|l|}
\hline \multicolumn{1}{|c|}{ Kuadran } & Posisi Titik & Luas Matrik & Ranking & Prioritas Strategi \\
\hline I - SO & $(2,46 ; 1,80)$ & 4,43 & 1 & Pertumbuhan \\
II - WO & $(0,64 ; 1,80)$ & 1,15 & 3 & Stabilitas \\
III - WT & $(0,64 ; 1,04)$ & 0,67 & 4 & Penciutan \\
IV - ST & $(2,46 ; 1,04)$ & 2,56 & 2 & Kombinasi \\
\hline
\end{tabular}




\section{$J M M$ UNRAM

Pada kuadran I (strategi SO) strategi umum yang dapat dilakukan oleh industri adalah menggunakan kekuatan untuk mengambil setiap keunggulan pada kesempatan yang ada. Pada kuadran II (strategi WO) industri dapat membuat keunggulan pada kesempatan yang ada sebagai acuan untuk memfokuskan kegiatan dengan menghindari kelemahan. Pada kuadran III (strategi WT) industri harus meminimumkan segala kelemahan untuk menghadapi setiap ancaman. Terakhir, pada kuadran IV (strategi ST) industri harus menjadikan setiap kekuatan untuk menghadapi setiap ancaman dengan menciptakan diversifikasi untuk menciptakan peluang.

\subsection{Perumusan Strategi Pengembangan}

Tahap berikutnya dalam analisa SWOT adalah menentukan strategi berdasarkan letak posisi kuadran. Industri kreatif kerajinan perhiasan mutiara kota Mataram terletak pada kuadran I dengan luas matrik 3,54. Luas matrik tersebut lebih besar dari luas matrik ketiga kuadran lainnya sehingga prioritas strategi yang dipilih adalah strategi SO. Strategi SO adalah stable growth strategi yaitu strategi yang memfokuskan pada penetrasi pasar, pengembangan pasar, dan pengembangan produk, integrasi (kedepan, kebelakang, horisontal) dan divesifikasi (konsentris, horisontal, konglomerasi).

Merujuk pada konsep umum strategi SO di atas, maka dapat dirumuskan strategi pengembangan industri kreatif kerajinan perhiasan mutiara Kota Mataram, sebagai berikut:

1. Penetrasi dan pengembangan pasar luar negeri. Sejauh ini pemasaran produk kerajinan perhiasan mutiara Lombok terbesar pada pelanggan domestik (dalam negeri). Pasar luar negeri memiliki tantangan tersendiri. Strategi efektif diperlukan oleh pengusaha-pengusaha dalam industri ini untuk mengatasi tantangan-tantangan adalah dengan menggunakan distributor/agen. Keterbatasan pengetahuan dan pengalaman pengusaha untuk melakukan pemasaran luar negeri dapat diatasi dengan keberadaan distributor.

2. Memiliki website perusahaan/industri. Cara pembeli domestik maupun luar negeri yang menjadi target market pemasaran perhiasan mutiara sudah pasti memiliki jaringan internet dan cenderung mencari informasi melalui internet. Salah satu cara yang efektif dalam memasarkan produk adalah memiliki website yang berisi profile perusahaan (produk dan informasi lain) dan e-mail resmi perusahaan-perusahaan.

3. Integrasi industri perhiasan mutiara dan bartu mulia atas dukungan kebijakan dan tehnologi untuk meningkatkan daya saing. Saat ini produk perhiasan mutiara laut selatan (south sea pearl) yang menguasai pemasaran dunia adalah Hongkong dan Jepang, dan mutiara Lombok (Indonesia) belum banyak dikenal.

4. Meningkatkan promosi dan branding harus terus menerus dilakukan. Pembentukan merek dagang bagi produk perhiasan mutiara lombok perlu segera dilakukan disertai pengembangan rantai penjualan baik dipasar dalam negeri maupun luar negeri. Sedangkan promosi dapat dilakukan melalui media apa saja untuk memperkenalkan produk baru, menjaring konsumen dan networking baru serta menjaga hubungan dengan konsumen lama agar selalu ingat pada produk Lombok.

5. Kreatif. Kemajuan industri perhiasan mutiara Lombok tidak terlepas dari kreatifitas pelaku dalam menciptakan desain produk. Meskipun pergerakan trend desain perhiasan tidak secepat trend desain busana namun kreatifitas dalam perhiasan sangat penting karena merupakan bagian dari industri fashion.

6. Membangun kepercayaan. Kesuksesan industri ini tidak lepas dari kejujuran. Produk berbahan baku mutiara harus jelas keterangannya sehingga sangat baik bilamana 


\section{$J M M$ UNRAM

produk yang dijual memiliki sertifikat. Badan yang memberi sertifikasi untuk produk mutiara adalah Swiss Gemmological Institute.

7. Membangun kebijakan untuk menjaga dan mempertahankan konservasi alam di kawasan budidaya mutiara/kawasan perairan laut pulau Lombok.

\section{KESIMPULAN}

\subsection{Kesimpulan}

Dari hasil penelitian yang telah dilakukan, maka kesimpulan yang dapat diambil atas penentuan strategi pengembangan melalui analisis SWOT dengan melakukan analisis faktor internal dan faktor eksternal pada industri kreatif sektor kerajinan perhiasan mutiara kota Mataram sebagai berikut:

1. Faktor internal yang terdiri dari kekuatan meliputi home made process sesuai selera pasar; jaringan pemasaran ke luar daerah sudah terbangun; kondisi keuangan stabil dan meningkat; reputasi yang baik dalam pelayanan baik dalam pemasaran, produksi dan kecepatan dalam pengiriman barang; dan keterampilan unik dan diwariskan. Sedangkan kelemahannya meliputi belum menggunakan mesin untuk pesanan volume besar sehingga proses produksi lambat; tidak mempunyai desain khusus yang bisa dijadikan komoditi utama; perencanaan sistem produksi belum maksimal masih ditentukan berdasarkan kebutuhan; dan modal usaha yang besar memiliki risiko tinggi.

2. Faktor eksternal yang terdiri dari peluang meliputi minat beli pelanggan yang besar untuk keperluan gaya; dukungan pemerintah dalam pengenalan produk melalui pameran pameran; kenaikan permintaan dalam beberapa tahun terakhir; dukungan pariwisata; dan pelestarian dan budidaya mutiara laut terus berkembang. Sedangkan ancamannya meliputi munculnya Jepang dan Hongkong sebagai kompetitor utama; adanya pesaing dari industri pabrikan; meningkatnya harga bahan baku; dan banyak sektor usaha baru yang membuat keterampilan ini ditinggalkan dan karyawan memilih profesi lain.

3. Strategi yang dapat digunakan untuk pengembangan industri kreatif sektor kerajinan mutiara di kota Mataram adalah stable growth strategi yaitu strategi yang memfokuskan pada penetrasi pasar, pengembangan pasar, dan pengembangan produk.

\subsection{Saran}

Berdasarkan hasil penelitian yang sudah dilakukan, peneliti berpendapat bahwa:

1. Dalam hal pemasaran kepasar luar negeri, pemerintah baik dari Kementerian Perdagangan maupun Bea Cukai perlu memberikan pengarahan tentang pilihan cara

masuk (entry modes) yang paling mungkin dengan biaya masuk dan risiko paling minimal.

2. Dalam hal produksi, pengrajin dalam industri sebaiknya terus meningkatkan keterampilannya dalam desain guna menunjang kesinambungan proses produksi yang sesuai dengan selera pemesan.

\subsection{Keterbatasan dan Arah Penelitian ke Depan}

Adapun keterbatasan dari penelitian ini dan arahan untuk penelitian ke depannya adalah sebagai berikut:

1. Di dalam penelitian ini tidak mempertimbangkan informasi dari pemerintah terkait dengan wujud dukungan dalam pengembangan produk kerajinan perhiasan mutiara, 


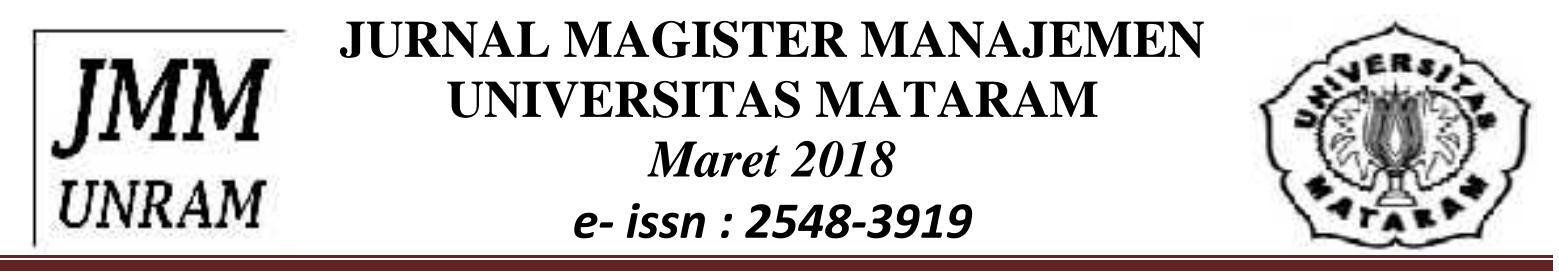

padahal cukup banyak program-program yang dijalankan oleh pemerintah untuk mengembangkan para pengusaha produk kerajinan perhiasan mutiara.

2. Penelitian ini hanya melihat aspek membandingkan kekuatan dengan kelemahan industri serta peluang dengan ancamannya. Sedangkan aspek tehnis yang meliputi aspek produksi, perbaikan desain, dan aspek fungsional tidak disertakan, padahal untuk produk kerajinan perhiasan mutiara aspek di atas menjadi penentu keunggulan bersaing industri.

\section{DAFTAR PUSTAKA}

Ahyari, Agus. 1983. Manajemen Produksi Perencanaan Sistem Produksi. Yogyakarta-BPFEYOGYAKARTA.

Aisyah Nurul Fitriana (2013), Pengembangan Industri Kreatif di kota Batu (Studi tentang Industri Kreatif Sektor Kerajinan di Kota Batu)Jurnal Administrasi Publik (JAP), Vol. 2 No. 2, Hal. 281-286, Universitas Brawijaya, Malang.

Anoraga, Pandji dan Djoko Sudantoko. 2002. Koperasi, Kewirausahaan, dan Usaha Kecil. Jakarta: PT Rineka Cipta.

Arikunto, Suharsimi. 2002. Prosedur Penelitian Suatu Pendekatan Praktek. Jakarta: PT Rineka Cipta.

Husein, Martani. 1993. Pengembangan Usaha Berskala Kecil di Indonesia.

Nazir, Moh, 1983, Metode Penelitian, Ghalia Indonesia , Jakarta.

Prasetyo, P Eko. 2004. Jurnal Ekonomi Dengan Judul “Strategi Pemberdayaan Industri Kecil dan Kerajinan Melalui faktor internal dan eksternal". Semarang: UNNES

Philip, Kottler. 2003. Manajemen Pemasaran. Klaten: PT. Indeks Gramedia.

Pangestu, Mari Elka (2008). "Pengembangan Ekonomi Kreatif Indonesia 2025", disampaikan dalam Konvensi Pengembangan Ekonomi Kreatif 2009-2015 yang diselenggarakan pada Pekan Produk Budaya Indonesia 2008, JCC, 4 -8 Juni 2008

Rangkuty, Freddy. 2006. Analisis SWOT Teknik Membedah Kasus Bisnis. Jakarta: PT Ikrar Mandiriabadi. 